\title{
Different Root Morphological Responses to Phosphorus Supplies in Grafted Pepper
}

\author{
Leandro PEREIRA-DIAS ${ }^{1}$, Lidia LOPEZ-SERRANO², Vicente CASTELL-ZEISING ${ }^{3}$, Salvador \\ LOPEZ-GALARZA ${ }^{3}$, Alberto SAN BAUTISTA ${ }^{3}$, Ángeles CALATAYUD ${ }^{2}$, Ana FITA ${ }^{1 *}$
}

\author{
${ }^{1}$ Instituto de Conservación y Mejora de la Agrodiversidad Valenciana (COMAV), Universitat Politècnica \\ de València, Camino de Vera 14, 46022 Valencia, Spain. \\ ${ }^{2}$ Instituto Valenciano de investigaciones agrarias (IVIA), Centro de Citricultura y Producción Vegetal, \\ Departamento de Horticultura, Valencia, Spain. \\ ${ }^{3}$ Universitat Politècnica de València. Departamento de Producción Vegetal, Spain \\ *corresponding author: anfifer@btc.upv.es
}

Bulletin UASVM Horticulture 75(1) / 2018

Print ISSN 1843-5262, Electronic ISSN 1843-536X

DOI:10.15835/buasvmcn-hort: 001217

\begin{abstract}
Grafting technique is increasing thanks to its potential to produce plants more efficient and tolerant to biotic and abiotic stresses. Likewise, there is a growing interest in reducing inputs of fertilizers. The development of rootstocks suitable for low input agriculture is conditioned to the understanding of the changes on the root when facing such stresses. Our aim was to evaluate the morphological root response to Phosphorus (P) starvation of a rootstock selected for its good performance under low $\mathrm{P}$ conditions. Adige was grafted onto the selected rootstock and grown hydroponically in two different $\mathrm{P}$ concentrations, the selft-graft was done as control. Plants were then collected and analysed. Results showed that despite the differences in terms of P concentration among treatment the stress was not enough to cause a great biomass loss. However, there is evidence that individuals showed different root adaptations, modifiying root length, mass and volume, etc, under stress conditions, having the selected rootstock higher root length and volume under low $\mathrm{P}$ nutrient solution
\end{abstract}

Keywords: root architecture, nutrient deficiency, Capsicum annuum, rootstock

\section{Introduction}

Nowadays, there is a growing interest in reducing fertilizer's inputs, both for economic and environmental reasons. This is particularly true in the case of phosphate fertilization since it causes eutrophication of the waters and also all P-fertilizers come from P-rock, a non-renewable source (Cordell et al., 2009; Vance et al., 2003). Therefore, the development of more efficient plants in terms of acquiring $\mathrm{P}$ is a new breeding goal (DenHerder et al., 2010; Lynch, 2007). This objective can be achieved by the use of more efficient rootstocks (Nawaz et al., 2016).

Pepper (Capsicum sp.) is one of the most relevant vegetable crop worldwide and an important area of soil is dedicated to its production (FAO, 2014). Grafting technique is used more and more in pepper to different objectives. (Penella et al., 2013) thanks to the potential of this technique to produce plants more efficient and resistant to biotic and abiotic stresses (Rivero et al., 2003). Recently some sources of tolerance to low $\mathrm{P}$ conditions have been identify as suitable for its use as rootstock in pepper (Pereira-Dias et al., 2016). However, the development and release of rootstocks suitable for low input in fertilizers is conditioned to the understanding of the changes on the root (plasticity) when facing such stresses.

Aims. In order to evaluate the morphological root response to phosphorus (P) starvation, a selected rootstock and the self-graft of a pepper variety were evaluated, under two different concentrations of phosphorus (P), for their root morphology and P content. 
Table 1. Mean values for $P$ concentration and dry biomass recorded on grafted plants (A and R rootstocks) under HP (1.5 mM P) and LP (0.5 mM P)

\begin{tabular}{ccccccc}
\hline & \multicolumn{2}{c}{$\mathrm{P}(\%)$ leaves } & \multicolumn{2}{c}{$\mathrm{P}(\%)$ roots } & \multicolumn{2}{c}{ Dry biomass $(\mathrm{g})$} \\
\hline & HP & LP & HP & LP & HP & LP \\
\hline A & 0,38 & $0,35^{*}$ & 1,85 & $0,80^{*}$ & 33,7 & 31,2 \\
\hline R & 0,38 & $0,33^{*}$ & 1,01 & $0,71^{*}$ & 30 & $\mathbf{2 7 , 2}$ \\
\hline
\end{tabular}

Note: Numbers of the same row with * indicate a significant difference with P-value $<0.05$. Numbers of the same column in bold indicate a significant difference with P-value $<0.05 \mathrm{Mean}$ values for $\mathrm{P}$ concentration and dry biomass recorded on grafted plants.

Table 2. Mean values for $\mathrm{P}$ concentration and dry biomass recorded on grafted plants (A and $\mathrm{R}$ rootstocks) under HP (1.5 mM P) and LP (0.5 mM P)

\begin{tabular}{ccccccccccccc}
\hline & \multicolumn{2}{c}{$\mathrm{LDW}(\mathrm{g})^{1}$} & \multicolumn{2}{c}{$\mathrm{L}(\mathrm{m})$} & \multicolumn{2}{c}{$\mathrm{D}(\mathrm{mm})$} & \multicolumn{2}{c}{$\mathrm{V}(\mathrm{cm} 3)$} & \multicolumn{2}{c}{$\mathrm{L}_{\mathrm{d}<1}(\mathrm{~m})$} & \multicolumn{2}{c}{$\mathrm{L}_{\mathrm{d}>1}(\mathrm{~m})$} \\
\hline & HP & LP & HP & LP & HP & LP & HP & LP & HP & LP & HP & LP \\
\hline A & 4,01 & $2,68^{*}$ & 219 & $155^{*}$ & 0,77 & 0,78 & 104 & $74^{*}$ & 178 & $126^{*}$ & 40 & $29^{*}$ \\
\hline R & 3,92 & $\mathbf{4 , 2 9}$ & $\mathbf{2 6 0}$ & $\mathbf{3 0 5}^{*}$ & 0,76 & 0,74 & 117 & $\mathbf{1 3 0}$ & $\mathbf{2 1 6}$ & $256^{*}$ & 44 & $\mathbf{4 8}$ \\
\hline
\end{tabular}

Note: Numbers of the same row with * indicate a significant difference with P-value $<0.05$. Numbers of the same column in bold indicate a significant difference with P-value $<0.05$

${ }^{1}$ LDW: lateral roots dry weight, RDW: total root dry weight, L: root length, D: root diamenter, V: root volume, Ld<: length of roots of diameter less or equal $1 \mathrm{~mm}, \mathrm{Ld}>1$ : length of roots of diameter more than $1 \mathrm{~mm}$.

\section{Materials and methods}

Adige, a Lamuyo type pepper, was grafted onto a rootstock (R) - selected in previous assays of grafting and low fertilization with $\mathrm{P}$ (data not shown). In addition, the self-graft of Adige was included as control (A). All grafted plants were grown hydroponically in two different concentrations of phosphorus $(0.5$ and $1.5 \mathrm{mM}$, named LP and HP, respectively). Size sample was 6 plants per genotype and per treatment. After 28 days of treatment all roots and shoots were collected and weighted (fresh and dry weight). Additionally, roots were spread in a transparent sheets, scanned and digitally analysed with WinRHIZO $^{\text {TM }}$ Pro (Regent Instruments Inc.) in order to evaluate possible changes in root morphology. $\mathrm{P}$ content in shoots and roots were analysed with ICP. Statistical analysis was performed using STATGRAPHICS Centurion XVI (StatPoint Technologies, Inc.)

\section{Results and discussion}

There were significant differences among treatments in terms of P concentration. The effect of the low concentration of $\mathrm{P}$ was observed more intensively in the roots (Tab. 1). However the treatment was not enough stressful to produce differences in terms of plant biomass. Despite of that, our findings indicate a differential response under LP conditions between grafts (Tab. 2). 'A' and ' $\mathrm{R}$ ' showed different root length (L) in HP conditions, in addition they respond in a different way to the LP condition: ' $\mathrm{A}$ ' individuals suffer a significant reduction of lateral roots dry weight (LDW), length (L), root volume (V) and length of roots of any diameter $\left(\mathrm{L}_{\mathrm{d}<1}\right.$ and $\left.\mathrm{L}_{\mathrm{d}>1}\right)$ under low $\mathrm{P}$ treatment. On the other hand, ' $\mathrm{R}$ ' individuals increased $L$ and $L_{d<1}$ and under low $P$ treatment. It has to be pointed out that these genotypes have different strategies to adapt to low $\mathrm{P}$ in the environment; ' $A$ ' reduces its expenses while ' $R$ ' tries to expand its foraging capacity by increasing roots volume. Different root morphologies in pepper have been reported previously (Fita et al., 2014; Fita et al., 2013; Pereira-Dias et al., 2016) but there is little previous information of the rootstock response to low $\mathrm{P}$ stress (Lopez-Serrano et al., 2017). In this experiment, the increased root system of ' $\mathrm{R}$ ' under LP conditions does not induce higher biomass of the scion. It needs to be 
noted that in hydroponic conditions increasing root length gives no advantage since the space is limited and the concentration of nutrient constant. However, in the soil an increased foraging capacity through longer roots can increase the nutrient uptake (Hodge, 2004). In this experiment, we did not reach flowering time nor harvest time. However, preliminary results in other experiments showed that sweet pepper grafted onto $\mathrm{R}$ had higher production in fields with low concentration of $P$ (data not shown) which could be a result of ' $R$ ' higher root length under LP.

\section{Conclusions}

Our results evidence a different response to low $\mathrm{P}$ input in terms of root architecture. Despite in our case the differences in terms of root architecture do not correlate with higher biomass in the scion, we believe that higher root length and volume would be advantageous in the field.

Acknowledgements: This assay was funded by the INIA project RTA2013-00022-C02 (FEDER funds) and APOTIP/2016/60 grant by the Generalitat Valenciana.

\section{References}

1. Cordell D, Drangert J, White S (2009). The story of phosphorus: Global food security and food for thought. Global Environmental Change-Human and Policy Dimensions 19: 292-305.

2. Den Herder G, Van Isterdael G, Beeckman T, De Smet I (2010). The roots of a new green revolution. Trends in plant science, 15(11): 600-607.

3. FAOSTAT (2014). FAO statistical data. http://faostat.fao. org

4. Fita A García MD, Raigón MD, Lerma MD, Moreno E, Rodríguez Burruezo A (2014). Peppers: soil dynamics, root architecture and fruit quality. EN Strategies for
Organic and Low-Input Integrated Breeding and Management (SOLIBAM). Final Congress: Diversity Strategies for Organic and Low Input Agricultures and Their Food Systems. (pp. 78-79). Nantes, France: INRA.

5. Fita A, Alonso-Valero I, Andrés J, Mateu MC, Rodríguez Burruezo A (2013). Evaluating Capsicum spp. root architecture under field conditions. EN XVth EUCARPIA Capsicum and Eggplant Working Group Meeting. (pp. 373-376). Torino, Italy: Universita degli Studi di Torino.

6. Hodge A (2004). The plastic plant: root responses to heterogeneous supplies of nutrients. New phytologist, 162(1): 9-24.

7. Lopez-Serrano L, Pereira-Días L, López G, Salvador V, San Bautista Primo A, Fita A, Calatayud A (2017). Differential response of grafted peppers depending on phosphorus concentration and genotype. EN XIV Solanaceae and III Cucurbitaceae Genomics Joint Conference (SOLCUC), (pp. 132 - 132). Valencia, Spain.

8. Lynch JP (2007). Roots of the second green revolution. Australian Journal of Botany, 55(5): 493-512.

9. Nawaz MA, Imtiaz M, Kong $Q$, Cheng F, Ahmed W, Huang Y, Bie Z (2016). Grafting: a technique to modify ion accumulation in horticultural crops. Front. Plant Sci., 7: 1457

10. Penella C, Nebauer S, Lopéz-Galarza S, SanBautista A, Gorbe E, Calatayud A (2013). Evaluation for salt stress tolerance of pepper genotypes to be used as rootstocks. J. Food Agric. Environ., 11(3-4): 1101-1107.

11. Pereira-Dias L, Gil Vilar D, Rodríguez Burruezo A, López Galarza SV, San Bautista Primo A, Castell Zeising V, Fita A (2016). Root morphology and phosphorus starvation adaptation in peppers. XVIth EUCARPIA Capsicum and Eggplant Working Group Meeting. Ed Diamond congress Ltd. ISSN 978-615-5270-27-7 (pp. 436-437).

12. Rivero RM, Ruiz JM, Romero L (2003). Role of grafting in horticultural plants under stress conditions. J. Food Agric. Environ., 1(1): 70-74.

13. Vance CP, Uhde-Stone C, Allan DL (2003). Phosphorus acquisition and use: critical adaptations by plants for securing a non-renewable resource. New Phytologist, 157(3): 423-447. 